\title{
Inter-annual variations of snow days over Switzerland from 2000-2010 derived from MODIS satellite data
}

\author{
N. Foppa and G. Seiz \\ Swiss GCOS Office, Federal Office of Meteorology and Climatology MeteoSwiss, Switzerland \\ Correspondence to: N. Foppa (nando.foppa@meteoswiss.ch)
}

Received: 7 September 2011 - Published in The Cryosphere Discuss.: 16 September 2011

Revised: 6 March 2012 - Accepted: 6 March 2012 - Published: 23 March 2012

\begin{abstract}
Snow cover plays a vital role in the Swiss Alps and therefore it is of major interest to determine and understand its variability on different spatiotemporal scales. Within the activities of the National Climate Observing System (GCOS Switzerland) inter-annual variations of snow days over Switzerland were derived from 2000 to 2010 based on data from the Moderate Resolution Imaging Spectroradiometer (MODIS) on board the Terra satellite. To minimize the impact of cloud cover on the MODIS snow product MOD10C1, we implemented a post-processing technique based on a forward and backward gap-filling approach. Using the proposed methodology it was possible to determine the total number of annual snow days over Switzerland from 2000 to 2010 (SCD MODIS). The accuracy of the calculated snow days per year were quantitatively evaluated against three in situ snow observation sites representing different climatological regimes $\left(\mathrm{SCD}_{\text {in_situ }_{-}}\right)$. Various statistical indices were computed and analysed over the entire period. The overall accuracy between $\mathrm{SCD}_{\text {MODIS }}$ and $\mathrm{SCD}_{\text {in_situ }}$ on a daily basis over $10 \mathrm{yr}$ is $88 \%$ to $94 \%$, depending on the regional characteristics of each validation site. Differences between $\mathrm{SCD}_{\mathrm{MODIS}}$ and $\mathrm{SCD}_{\text {in_situ }}$ vary during the snow accumulation period in autumn and smaller differences after spring, in particularly for the Central Alps.
\end{abstract}

\section{Introduction}

Snow cover represents a significant geophysical variable for the climate system through a range of complex interactions and feedback mechanism related to its physical properties (IPCC, 2007). High priority is therefore accorded in the Implementation Plan of the Global Climate Observing System (GCOS) to strengthen and maintain snow cover observations, ideally supplemented with other observing systems (WMO, 2006, 2010).
The estimation of snow parameters such as snow extent, snow depth, and snow water equivalent plays a vital role in the Swiss Alps for winter tourism as well as for the management of water resources (e.g. Elsasser and Messerli, 2001; Abegg et al., 2007; Uhlmann et al., 2009). Therefore, ground-based monitoring of the snow cover has a long tradition in Switzerland and a number of studies have been published over the last years, focusing on its temporal variability and long-term trend (Beniston, 1997; Laternser and Schneebeli, 2003; Scherrer et al., 2004; Scherrer and Appenzeller, 2006; Marty, 2008). Overall, these results describe a decrease of the alpine snow pack since the mid 1980's especially at lower altitudes which is linked to an increase of local winter temperatures (Scherrer et al., 2012). Most of these studies focused on the spatiotemporal variability of days with snow cover. Beside snow measurements (e.g. new snow depth), the number of snow days is an important climatological indicator serving applications in tourism, transportation, construction, or agriculture. In general, a snow day is defined as a day with a snow depth larger than a certain threshold (WMO, 2009). Different thresholds are published to derive the number of snow days for climatological applications (e.g. Eckel, 1938; Hantel et al., 2000; Laternser and Schneebeli, 2003; Scherrer and Appenzeller, 2006; Marty, 2008).

Compared to ground-based observations with the limitation of being sparse, satellite data give an area-wide and spatially consistent information of the ground or atmosphere. For more than three decades, satellite remote sensing has been used to measure snow properties from drainage-basin to continental scales (Hall and Martinec, 1985). With the continuity of Earth Observation programs of climate relevant sensors, satellite data series will be further extended and the development of new satellite systems will provide the retrieval of critical measurements. Concerning satellite-based snow cover monitoring, climatological studies on a decadal and hemispherical to regional scale were carried 
out (e.g. Robinson and Frei, 2000; Armstrong and Brodzik, 2001; Bales et al., 2008; Foster et al., 2009; Boi, 2010). For Switzerland, polar-orbiting NOAA AVHRR data (Foppa et al., 2004, 2006) and geostationary Meteosat SEVIRI data (De Ruyter de Wildt et al., 2007) were used for the near-realtime retrieval of the snow cover extent and thereof derived climatological pilot studies (Seiz et al., 2007; Foppa et al., 2008).

In this study, we focus on the inter-annual variations of snow cover days (SCD) from October 2000 to September 2010 based on data from the Moderate Resolution Imaging Spectroradiometer (MODIS) on board the Terra platform. The purpose is to examine the spatiotemporal variation of the snow conditions on a yearly basis over Switzerland. A simple cloud gap-filling technique is implemented by post-processing the MOD10C1 product to derive the number of days with snow cover. The multi-year time series of SCD on an annual basis are compared with selected in situ snow observations and further discussed on a monthly and daily resolution to demonstrate the potential of our SCD product. The study reported here is placed in the broader context of the satellite activities within the National Climate Observing System of Switzerland (GCOS Switzerland) (Seiz and Foppa, 2007, 2011; Seiz et al., 2011).

\section{Data}

\subsection{MODIS satellite data}

Within this study the MODIS/Terra Snow Cover Daily L3 Global 0.05 Deg Climate Modeling Grid (CMG) Version 5 (MOD10C1) product was used, obtained from the National Snow and Ice Data Center (NSIDC). The data set spans the period from the 1 October 2000 to 30 September 2010. Version 5 (V005), also known as Collection 5, is the most current version of data available from NSIDC. In the MOD10C1 product, a binning algorithm maps MOD10A1 daily snow cover data at $500 \mathrm{~m}$ resolution into a grid of a 0.05 degree $(\mathrm{CMG})$ and calculates snow and cloud percentages, Quality Assessment (QA), and a confidence index based on the mapping results. The algorithm generates these parameters based on the total number of observations of a class (snow, cloud, land, and others) and the total number of land observations mapped into a grid cell of the CMG (Riggs et al., 2006). The MODIS snow cover retrieval is based on the Normalized Difference Snow Index (NDSI) and further criteria tests (Hall et al., 2002; Hall and Riggs, 2007). A number of studies have assessed the accuracy of the MODIS snow cover algorithm and its derived products on a regional scale (e.g. Klein and Barnett, 2003; Tekeli et al., 2005; Parajka and Blöschl, 2006). A comprehensive overview of the MODIS-based snow products and validation studies is given in Parajka and Blöschl (2011).

\subsection{In situ snow observations}

In Switzerland, snow variables such as total snow depth and new snow depth are measured mainly by the Federal Office of Meteorology and Climatology MeteoSwiss and the Swiss Federal Institute for Snow and Avalanche Research (SLF) in Davos. The observations consist of either manually or automatically recording stations. The amount of new snow depth and total snow depth at conventional stations is measured twice daily (morning and evening) by an observer on a representative plot in horizontal terrain (Bezzola, 2004). This network of conventional observations covers the entire region of Switzerland. The advantage of manual observations is the longer time series of up to more than $50 \mathrm{yr}$ providing valuable information for climatological studies. Over the past few years, efforts have been made to identify, digitize and explore snow measurements from historical data sources dating back to the second half of the 19th century (Wüthrich, 2008). A recently published report by MeteoSwiss (Wüthrich et al., 2010) defined a potential basic climatological network for snow, based on the analysis of 160 historical snow measurement series. In our study, three stations have been selected from this so-called National Basic Climatological Network for Snow (NBCN-S) representing main climatological regimes in Switzerland and varying altitudes (Table 1). All in situ observation data have been well quality controlled and verified through various standard quality processing steps (Bezzola, 2004). In our study, we defined snow days with a snow depth of at least $1 \mathrm{~cm}\left(\mathrm{SCD}_{\text {in_situ }_{1}}\right)$ as used at MeteoSwiss.

\section{Method for satellite-derived snow days}

A weakness of optical satellite sensors is that they are not able to see the ground in cloudy conditions in contrast to in situ observations. The spectral specifications of the MODIS sensor do not allow for observations of the Earth's surface under cloudy conditions, which is a major limitation for studies of snow cover. This particularly applies to areas with frequent cloud cover, e.g. mountain regions such as the Alps. The MOD10C1 snow cover product uses the ancillary MODIS cloud mask (i.e. MOD35 product) based on cloud-detection tests indicating a level of confidence that MODIS observes clear skies (Ackerman et al., 1998; Platnick et al., 2003).

Several techniques have been developed to reduce the cloud cover pixels from MODIS products. They include one or a combination of different approaches, such as spatial filtering (Parajka and Blöschl, 2008; Gafurov and Bárdossy, 2009; Xie et al., 2009), temporal filtering, temporal composites of maximum snow cover extent, prior cloud-persistence and combining Terra and Aqua MODIS data (Parajka and Blöschl, 2008; Gafurov and Bárdossy, 2009; Wang et al., 2009; Hall et al., 2010). 
Table 1. Location of the selected in situ snow stations.

\begin{tabular}{llrrr}
\hline Station & Region & Latitude & Longitude & Altitude [m a.s.l.] \\
\hline Basel & Swiss Plateau & 47.54 & 7.58 & 316 \\
Samedan & Central Alps & 46.53 & 9.87 & 1708 \\
Lugano & Southern Alps & 46.01 & 8.96 & 370
\end{tabular}

To produce a consistent daily MODIS snow cover map at 0.05 degree resolution, we applied a post-processing technique to fill data gaps in the MOD10C1 product caused by clouds. The methodology uses a combination of thresholds in the post-processing of the MODIS product and a subsequent two step gap-filling approach as described below.

In a first step, we re-classified the pixels as follows: if cloud percentage of a CMG cell is $>95 \%$ the pixel is re-classified as cloud covered; if snow percentage of a CMG cell is $>4 \%$ and cloud percentage $\leq 95 \%$, the pixel value is then normalized, resulting in a snow fraction related to the cloud free land observed (confidence index). If the CMG snow cover is less than $4 \%$ and the CMG cloud observation is less than $95 \%$, the grid cell is defined as snow free. In a second step, a cloudy pixel is replaced by the latest cloud free (snow fraction or snow free) observed pixel information. Even though the number of consecutive days with cloud cover could accumulate over time, the gaps are filled with the same value provided from the latest cloud-free grid cell. In accordance to this so-called forward gap-filling approach, we applied the same procedure in reverse direction (backward gap-filling), e.g. 30 September 2003 to 1 October 2002, filling the cloud covered grid cells (e.g. 17 October 2000) with the cloud-free information from the day "before" (e.g. 18 October 2000). Following the forward and backward gap-filling technique, daily "cloud-free" products are generated. We assume that through the exactly opposite gap-filling of forward and backward technique, the over- or underestimation in one of the directions is minimized. As we focus on a yearly temporal resolution, we calculate the mean of the total number of snow days derived from the forward and backward gap-filling procedure. Data gaps were treated as cloudy conditions. Furthermore, information from the last or first day of the neighbouring year was not taken into account if the first or last day of the year was cloud covered. The MODIS derived snow cover days ( $\mathrm{SCD}_{\mathrm{MODIS}}$ ) are calculated for the hydrological year starting 1 October of any given year and end on 30 September of the subsequent year. It should be noted that this procedure is usable for data re-processing only, comparable to nowcast (forward gap-filling) and hindcast (backward gap-filling) modeling. It is the intention to derive the total number of snow days on a yearly time resolution.

\section{Results}

\subsection{0-yr snow cover climatology based on SCD}

Figure 1 shows the $\mathrm{SCD}_{\text {MODIS }}$ maps binned into 15 classes on a 25-days interval basis. The SCD MODIS maps highlight the number of snow days for the period of 1 October to 30 September for the years 2000-2010, representing different snow conditions. It is clearly visible that the $\mathrm{SCD}_{\text {MODIS }}$ product reflects the topography of Switzerland with larger number of snow days in higher altitudes and less days with snow cover in the Swiss midlands and in Southern Switzerland. Regions with less than 25 days of snow cover per year are mostly found in the Rhein Valley, in France and in the plain of the Po River in Northern Italy. The inter-annual spatial variations are most apparent on the Swiss Plateau whereas in the Central Alps the year to year variability is marginal. The years 2001/2002 and 2006/2007 are outstanding with a relatively small number of days with snow particularly in the Swiss lowlands. In contrary, the years 2004/2005 and 2008/2009 demonstrate years with a relatively large number of days with snow in the Swiss lowlands.

Figure 2 shows the temporal evolution and variability of the total number of snow days for each year from 2000 to 2010 for the three selected stations based on MODIS

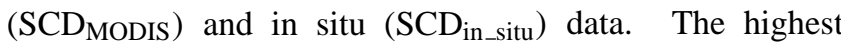
located station Samedan has at least 130 days with snow per year with up to more than 200 for 2008/2009. At the stations Basel and Lugano, some years without snow occurred. The year with a larger number of snow days for Lugano (2008/2009) is reflected in the corresponding maps in Fig. 1 for the region of northern Italy. The year 2006/2007 is characterized with the minimum number of snow days over the $10 \mathrm{yr}$, except for Basel and Samedan. In general, the inter-annual variability of snow days derived from in situ observations over the $10 \mathrm{yr}$ is captured very well by our post-processed MOD10C1 product. The annual total number of snow days derived from MODIS is higher compared to the in situ defined number of snow days for 7 out of the $10 \mathrm{yr}$ in Basel and for 9 out of the $10 \mathrm{yr}$ in Lugano, respectively. Only at Samedan the in situ based number of snow days is in 6 out of the $10 \mathrm{yr}$ higher than the satellite-derived number of snow days. However, the absolute differences between $\mathrm{SCD}_{\mathrm{MODIS}}$ and $\mathrm{SCD}_{\text {in_situ }}$ vary significantly between the three stations with a maximum discrepancy of 33 days (18\%) for Samedan in 2002/2003. At Basel (2002/2003) and Lugano (2008/2009), largest differences of 16 days (34\%) and 18 days $(50 \%)$ are found, respectively.

The MODIS derived snow cover days ( $S C D_{\text {MODIS }}$ ) versus the in situ based calculated snow days $\left(\mathrm{SCD}_{\text {in_situ }}\right)$ for the three stations and over the $10 \mathrm{yr}$ is summarized in Table 2. The mean absolute difference $d$, the standard deviation of the difference $s$ and the correlation coefficient $c$ is indicated for each station (Table 2). Additionally the 

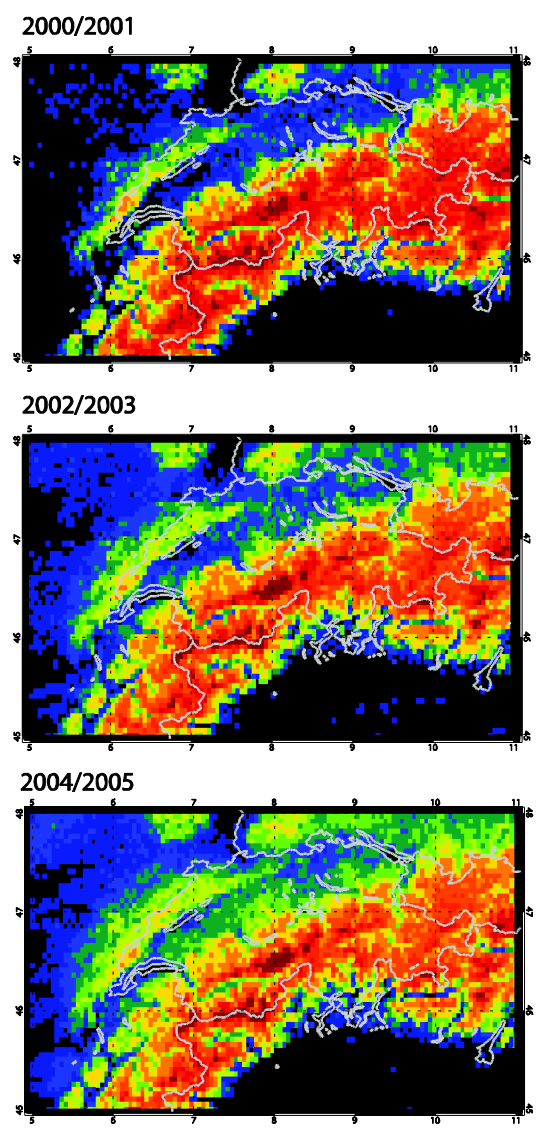

$2006 / 2007$

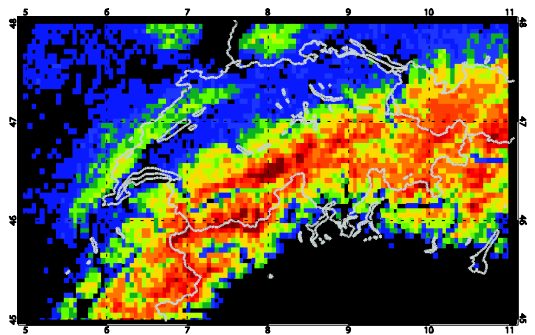

$2008 / 2009$

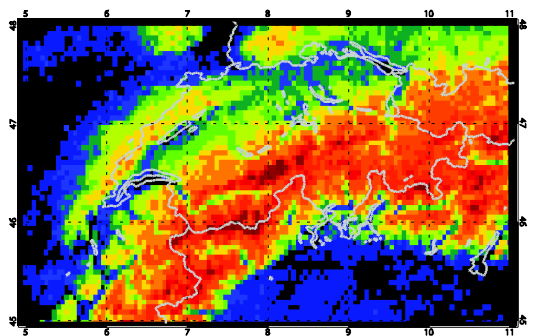

$2001 / 2002$

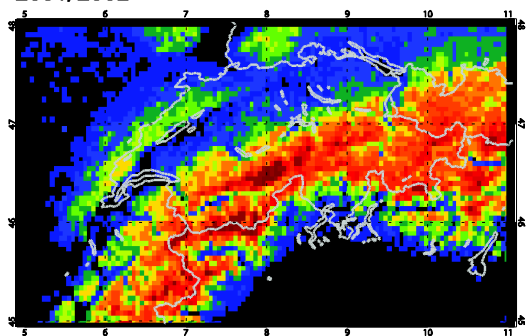

$2003 / 2004$

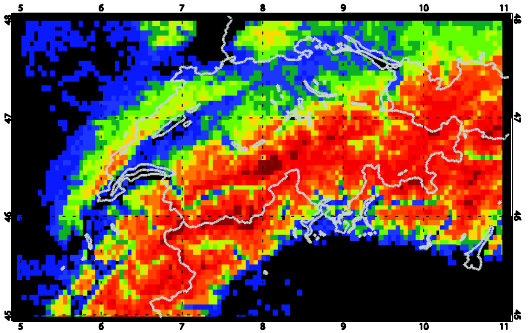

$2005 / 2006$

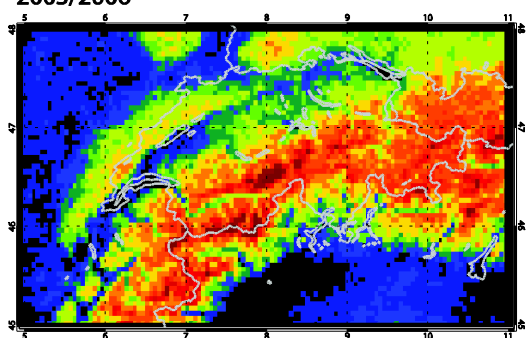

2007/2008

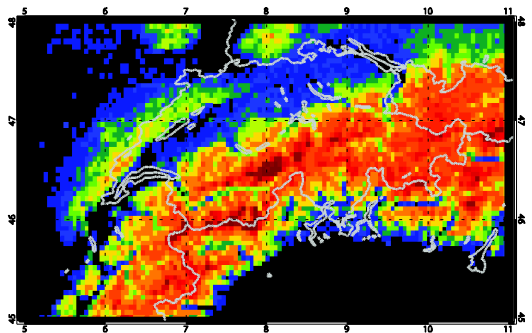

$2009 / 2010$

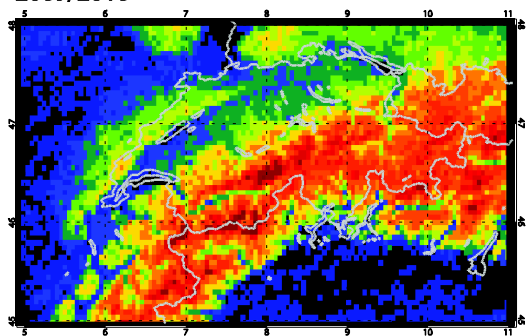

Number of days with snow

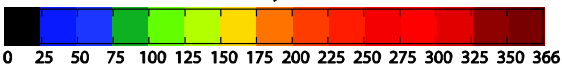

Fig. 1. Satellite-derived number of days with snow per year over Switzerland from 2000 to 2010. 

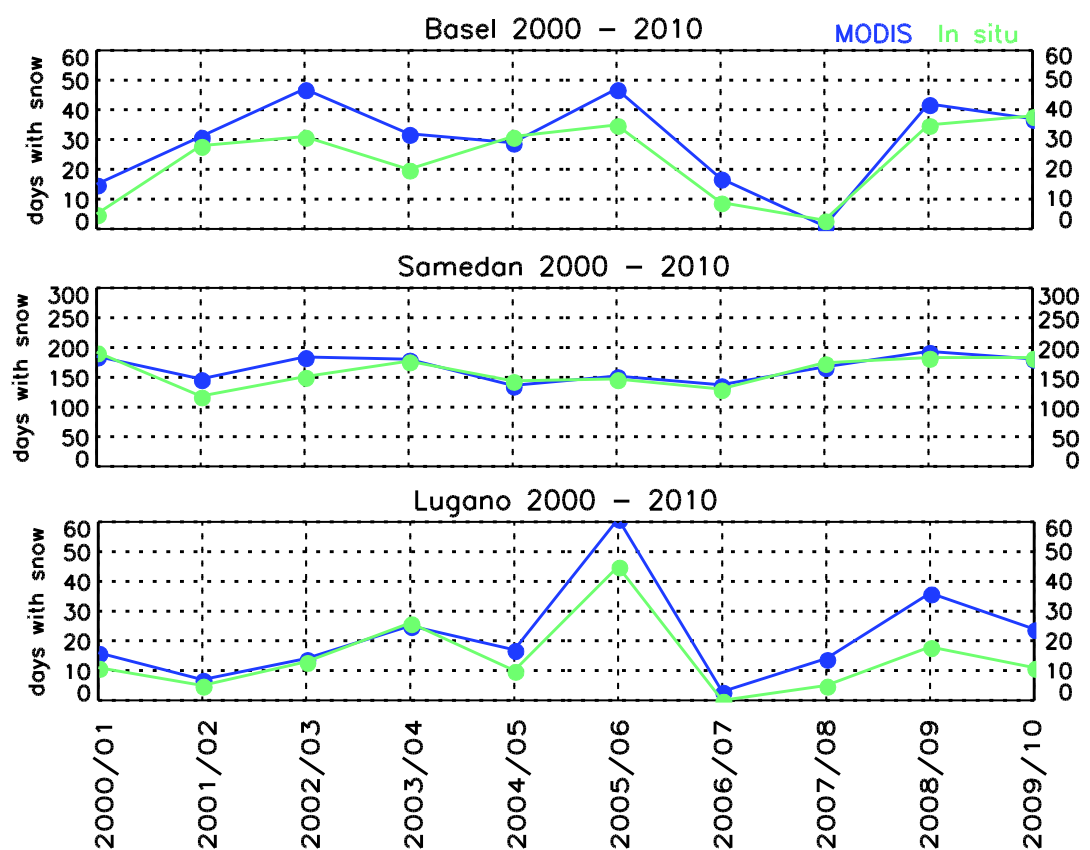

Fig. 2. Temporal variability of the total yearly number of snow days from 2000-2010 for Basel (Swiss Plateau), Samedan (Central Alps) and Lugano (Southern Alps) in Switzerland.

Table 2. $\mathrm{SCD}_{\mathrm{MODIS}}$ versus $\mathrm{SCD}_{\text {in_situ }}$ on a yearly basis $(d=$ mean absolute difference of $\mathrm{SCD}_{\mathrm{MODIS}}-\mathrm{SCD}_{\text {in_situ }}, \quad s=$ standard deviation, $c=$ coefficient of correlation, $d(\%)=$ relative difference). $\mathrm{SCD}_{\text {in_situ }}$ indicates the averaged number of days with snow over the $10 \mathrm{yr}$ and $\mathrm{cc}$ is the averaged annual cloud cover in percent derived from the MOD10C1 product.

\begin{tabular}{lrrr}
\hline & $\begin{array}{r}\text { Basel: } \\
\text { Swiss Plateau }\end{array}$ & $\begin{array}{r}\text { Samedan: } \\
\text { Central Alps }\end{array}$ & $\begin{array}{r}\text { Lugano: } \\
\text { Southern Alps }\end{array}$ \\
\hline$d$ & 6.30 & 6.30 & 7.30 \\
$s$ & 6.48 & 14.46 & 6.55 \\
$c$ & 0.90 & 0.82 & 0.93 \\
$d(\%)$ & 54.1 & 7.7 & 66.7 \\
SCD $_{\text {in_situ }}$ & 24 & 160 & 14 \\
cc $(\%)$ & 50.59 & 42.26 & 38.84 \\
\hline
\end{tabular}

relative difference is presented $(d \%)$ as well as the annual mean of the total number of snow days derived from in situ measurements $\left(\mathrm{SCD}_{\text {in_situ }}\right)$ and the annual mean of the cloud cover based on the MOD10C1 cloud obscuration. The $10 \mathrm{yr}$ average of $\mathrm{SCD}_{\mathrm{in}_{\text {_situ }}}$ and cloud cover refers to the regional characteristics of each of the three sites. Although the statistical evidence is based on a small sample, a certain tendency of the discrepancy is obvious. Overall, the satellite based total number of days with snow agrees well $(c>0.8)$ with a slight overestimation of up to 7 days. However, the standard deviation of the difference is twice as high for Samedan as for Basel or Lugano $(s=14.46)$. The multi-year average of the relative errors are quite large for the lowland stations Basel (54\%) and Lugano (67\%) whereas it is small for the alpine site Samedan. It should be noted that the large relative discrepancies are resulting from the small number of snow days in Basel and Lugano.

\subsection{Analysis of monthly SCD}

Table 3 summarizes the results of the comparison of

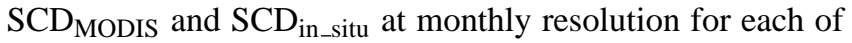
the three sites. To demonstrate the effect of the satellite derived snow cover days relative to the climatology we calculate the Climatological Skill Score $\left(\mathrm{SS}_{\text {clim }}\right)$ following the description and equations by Wilks (2006).

$\mathrm{SS}_{\text {clim }}$ is positive when $\mathrm{SCD}_{\text {MODIS }}$ is better than the climatological estimation. However, is not possible to calculate this $\mathrm{SS}_{\text {clim }}$ when the Mean Squared Error (MAE) is zero (no snow days observed in all month over the $10 \mathrm{yr}$ ). Additionally, the monthly average of the snow days defined by in situ measurements and of the cloud coverage based on the MOD10C1 cloud mask is indicated. The total number of snow days based on MODIS differs from the in situ observations for most of the month. Outstanding is the month February (Basel and Lugano) and the period January to April at Samedan with a positive bias. Largest negative deviations are found at the beginning of the snow season (October, November), when ephemeral snow fall is frequently observed, especially at high elevation sites such as Samedan. In the Southern Alps at Lugano, highest biases 
Table 3. Mean difference of $\mathrm{SCD}_{\text {MODIS }}-\mathrm{SCD}_{\text {in_situ }}(d)$ and standard deviation of the difference $(s)$ as well as the Climatological Skill Score $\left(\mathrm{SS}_{\mathrm{clim}}\right)$. The number of snow days $\left(\mathrm{SCD}_{\mathrm{in} \_ \text {situ }}\right)$ and the cloud cover in percent (cc) averaged over each month for the $10 \mathrm{yr}$ and each station site is added. It is not possible to calculate $\mathrm{SS}_{\mathrm{clim}}$ when the Mean Squared Error (MAE) is zero (no snow days observed in all month over the $10 \mathrm{yr})$.

\begin{tabular}{|c|c|c|c|c|c|c|c|c|c|c|c|c|}
\hline & Oct & Nov & Dec & Jan & Feb & Mar & Apr & May & Jun & Jul & Aug & Sep \\
\hline \multicolumn{13}{|l|}{ (a) Basel } \\
\hline$d$ & 1.50 & 1.30 & 1.70 & 0.30 & -0.50 & 1.00 & 0.40 & 0.30 & 0.00 & 0.10 & 0.00 & 0.20 \\
\hline$s$ & 2.07 & 1.77 & 4.27 & 3.95 & 2.01 & 4.27 & 1.51 & 0.95 & 0.00 & 0.32 & 0.00 & 0.42 \\
\hline $\mathrm{SS}_{\mathrm{clim}}$ & 0.16 & 0.26 & 0.31 & 0.74 & 0.83 & 0.30 & -0.01 & 0 & - & 0 & - & 0 \\
\hline $\mathrm{SCD}_{\text {in_situ }}$ & 0.2 & 0.7 & 4.0 & 9.2 & 6.2 & 2.9 & 0.3 & 0.0 & 0.0 & 0.0 & 0.0 & 0.0 \\
\hline $\operatorname{cc}(\%)$ & 53.2 & 62.0 & 70.6 & 61.9 & 62.1 & 54.8 & 46.3 & 45.8 & 37.0 & 36.5 & 40.3 & 36.6 \\
\hline \multicolumn{13}{|c|}{ (b) Samedan } \\
\hline$d$ & 2.90 & 2.20 & 0.40 & -1.10 & -0.50 & -0.10 & -0.10 & 1.60 & 0.30 & 0.20 & 0.30 & 0.20 \\
\hline$s$ & 2.64 & 3.71 & 5.58 & 2.13 & 0.71 & 1.52 & 7.96 & 3.03 & 1.42 & 0.79 & 0.67 & 1.87 \\
\hline $\mathrm{SS}_{\text {clim }}$ & 0.20 & 0.70 & -0.17 & -5.50 & 0.73 & 0.36 & 0.45 & -1.45 & -3.60 & -5.70 & - & -2.17 \\
\hline $\mathrm{SCD}_{\text {in_situ }}$ & 3.8 & 17.6 & 28.7 & 30.7 & 27.7 & 30.1 & 17.9 & 2.3 & 0.3 & 0.1 & 0.0 & 0.7 \\
\hline $\operatorname{cc}(\%)$ & 37.4 & 41.0 & 40.3 & 42.3 & 43.6 & 52.3 & 55.7 & 56.5 & 40.0 & 30.6 & 37.4 & 30.0 \\
\hline \multicolumn{13}{|l|}{ (c) Lugano } \\
\hline$d$ & 0.70 & 0.20 & 2.10 & 3.60 & -0.70 & 0.10 & 0.20 & 0.00 & 0.40 & 0.10 & 0.32 & 0.30 \\
\hline$s$ & 1.64 & 0.79 & 3.90 & 5.10 & 2.41 & 0.57 & 0.63 & 0.00 & 0.97 & 0.32 & 0.95 & 0.67 \\
\hline $\mathrm{SS}_{\text {clim }}$ & - & 0.10 & 0.41 & -0.63 & 0.67 & 0.33 & - & - & - & - & - & - \\
\hline $\mathrm{SCD}_{\text {in_situ }}$ & 0.0 & 0.4 & 4.8 & 5.2 & 3.5 & 0.5 & 0.0 & 0.0 & 0.0 & 0.0 & 0.0 & 0.0 \\
\hline $\operatorname{cc}(\%)$ & 48.1 & 50.0 & 45.8 & 46.1 & 44.3 & 41.6 & 45.0 & 37.4 & 30.7 & 21.6 & 25.5 & 30.0 \\
\hline
\end{tabular}

are noted later in winter (December, January). As the snow season advances, the agreement increases quite constantly. For a large part of the months the $\mathrm{SS}_{\mathrm{clim}}$ is positive, referring to an improvement over the climatological estimations based on in situ only. This tendency is demonstrated for all three sites during the winter months except for January at Lugano and Samedan. At Samedan, the negative $\mathrm{SS}_{\text {clim }}$ values occur from late spring (May) to early autumn (September) when the climatology is of larger significance. Inter-monthly variations of the cloud cover are clearly visible for each station with different cloud cover maxima and minima for each site and region.

Figure 3 shows the month to month variations and differences from October 2000 to September 2010, exemplified for Samedan. Overall, the monthly variations from MODIS and in situ correspond quite well. Periods with complete snow cover (December, January, February, March) are generally captured by SCD MODIS in every year. A somewhat lower agreement is found during the transition periods in fall (October, November) and spring (April, May). Differences of more than 5 days per month are registered in November (e.g. 2002), December (15 days in 2001), April (19 days in 2002) and May (2003).

\subsection{Analysis of daily SCD}

Daily data were analysed to further examine the discrepancies between both data sets. The results are reported in Fig. 4 for Samedan for the 2002/2003 season. A total of 185 snow days were extracted from the MODIS post-processed product, as opposed to 152 days determined from in situ observations (i.e. a difference of 33 days). Figure 4a illustrates the snow cover fraction (blue) and the frequency and duration of cloud coverage from the daily MOD10C1 product (light brown) and the defined snow free days (green). The longest period of cloud cover occurs at the end of December ( 8 days) and a maximum cloud free period of up to 20 days in February. Figure $4 b$ and c explain the forward and backward gap-filling approach by artificial adding of additional days with snow and days with no snow, respectively. The complementary effect of these opposite processes is explained in Fig. 4d: contrary gap-filling results are detected between the middle of October and beginning of November. While the forward approach substitutes cloud cover with snow free land, the backward approach does fill the cloud obscured days with snow. The months of October (+7 days), November (+6 days), and extensively April (+19 days), are causing a larger total number days with snow per year compared to the in situ observations (Fig. 4e).

A confusion matrix (e.g. Pu et al., 2007) was constructed to better assess the overall accuracy of the gap-filling technique. Table 4 presents three confusion matrices for Basel (a), Samedan (b) and Lugano (c), based on a daily comparison between SCD 1 October 2000 to 30 September 2010. The results of the forward $\left(\mathrm{SCD}_{\mathrm{F}}\right)$ and backward $\left(\mathrm{SCD}_{\mathrm{B}}\right)$ gap-filling 

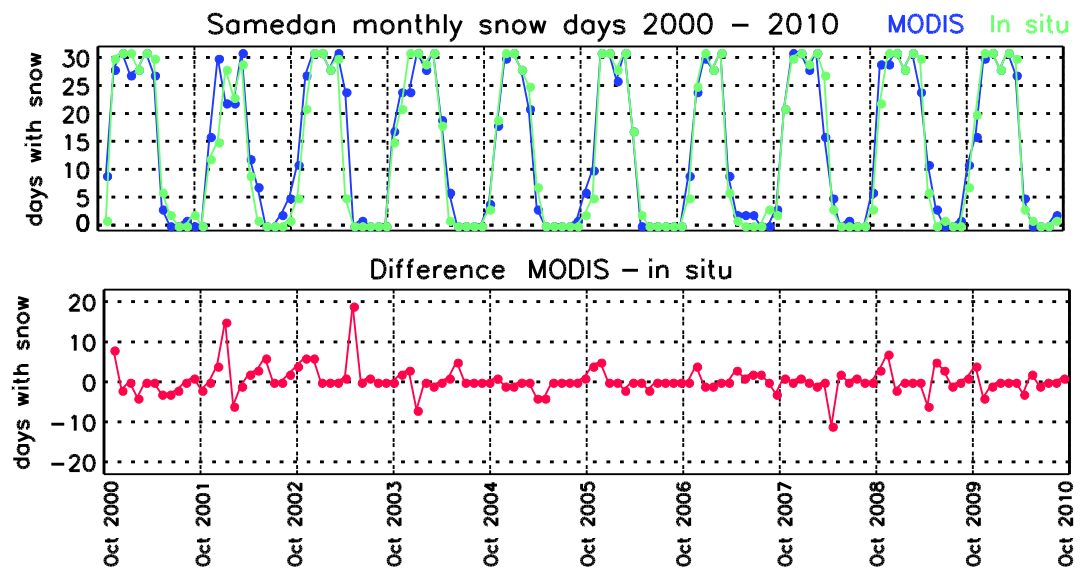

Fig. 3. Temporal variability of the monthly number of snow days and the differences $\left(\mathrm{SCD}_{\mathrm{MODIS}}-\mathrm{SCD}_{\mathrm{in} \_ \text {situ }}\right)$ from $2000-2010$ for Samedan.

Table 4. Confusion matrix for SCD MODIS compared with in situ derived snow days ( $\left.\mathrm{SCD}_{\text {in_situ}}\right)$ from 1 October 2000 to 30 September 2010 on a daily basis for all three sites.

\begin{tabular}{|c|c|c|c|c|c|}
\hline & & \multicolumn{4}{|c|}{ SCD $_{\text {MODIS }}$} \\
\hline & & $\begin{array}{l}\mathrm{SCD}_{\mathrm{F}_{\text {_snow }}} \\
\mathrm{SCD}_{\mathrm{B} \text { _snow }}\end{array}$ & $\begin{array}{l}\mathrm{SCD}_{\mathrm{F}_{\text {_snow }}} \\
\mathrm{SCD}_{\mathrm{B} \text { _snowfree }}\end{array}$ & $\begin{array}{l}\mathrm{SCD}_{\mathrm{F} \text { snowfree }} \\
\mathrm{SCD}_{\mathrm{B} \text { _snow }}\end{array}$ & $\begin{array}{l}\mathrm{SCD}_{\mathrm{F} \text { _snowfree }} \\
\mathrm{SCD}_{\mathrm{B} \_ \text {snowfree }}\end{array}$ \\
\hline \multicolumn{6}{|l|}{ (a) Basel } \\
\hline \multirow{2}{*}{$\mathrm{SCD}_{\text {in_situ }}$} & SCD in_situ_snow & $2.6[\%]$ & $1.4[\%]$ & $1.4[\%]$ & $1.1[\%]$ \\
\hline & $\mathrm{SCD}_{\text {in_situ_snowfree }}$ & $1.2[\%]$ & $2.9[\%]$ & $3.5[\%]$ & $85.8[\%]$ \\
\hline \multicolumn{6}{|l|}{ (b) Samedan } \\
\hline \multirow{2}{*}{$\mathrm{SCD}_{\text {in_situ }}$} & $\mathrm{SCD}_{\text {in_situ_snow }}$ & $39.5[\%]$ & $1.0[\%]$ & $2.0[\%]$ & $1.5[\%]$ \\
\hline & $\mathrm{SCD}_{\text {in_situ_snowfree }}$ & $3.7[\%]$ & $1.3[\%]$ & $1.7[\%]$ & $49.2[\%]$ \\
\hline \multicolumn{6}{|l|}{ (c) Lugano } \\
\hline \multirow{2}{*}{$\mathrm{SCD}_{\text {in_situ }}$} & SCD in_situ_snow & $2.4[\%]$ & $0.2[\%]$ & $0.8[\%]$ & $0.6[\%]$ \\
\hline & $\mathrm{SCD}_{\text {in_situ_snowfree }}$ & $2.0[\%]$ & $1.2[\%]$ & $1.5[\%]$ & $91.3[\%]$ \\
\hline
\end{tabular}

approach are combined for snow covered (e.g. SCDF_snow) and snow free days (e.g. $\mathrm{SCD}_{\mathrm{B}_{\text {_snowfree }}}$ ). Both satellite-based gap-filling approaches incorrectly substitute cloudy pixels as snow covered in $1.2 \%$ and $2.0 \%$ of all days (commission errors) for Basel and Lugano, respectively. At Samedan around $3.7 \%$ of all days are incorrectly defined as snow covered by the post-processed MOD10C1 product instead of snow free. In contrast, an incorrect replacement of cloud coverage with snow free observations occurs in about $1 \%$ of all days for all three sites (omission errors). The fraction of inconsistent gap-filling results (e.g. $\mathrm{SCD}_{\mathrm{F}_{\text {_snow }}}$ and $\left.\mathrm{SCD}_{\mathrm{B} \_ \text {snowfree}}\right)$ on the total number of days varies between $3.8 \%$ for Lugano, $6.1 \%$ for Samedan and a maximum of $9.3 \%$ for Basel.

Based on the confusion matrices in Table 4 we further calculated statistical indicators following the description in Boi (2010) and Zappa (2008). We computed the hit rate (HIT), the probability of detection (POD), the false alarm rate (FAR), and the threat score (TS) for all three sites including daily observations of SCD from 1 October 2000 to 30 September 2010 (Table 5). For Basel and Samedan the overall accuracy expressed as HIT is quite similar and high at $88 \%$ and $89 \%$, respectively. At the site Lugano the agreement is even higher at $94 \%$. However, the HIT is influenced by the most common category such as no snow days in Basel and Lugano and snow days in Samedan. FAR is significant smaller for Samedan than for Basel and Lugano due to the sensitivity to incorrectly defined snow days by excluding missed snow days. As indicated by the FAR, there are some false alarms while the POD of Samedan is near the ideal value of 1 . TS takes into account the missed snow days and gives an idea of accuracy for situations where rare events are involved (e.g. Basel and Lugano). At Samedan there are some false alarms (FAR of $4.0 \%$ ) resulting in a TS of 0.88 , considerable higher than for Basel and Lugano. 

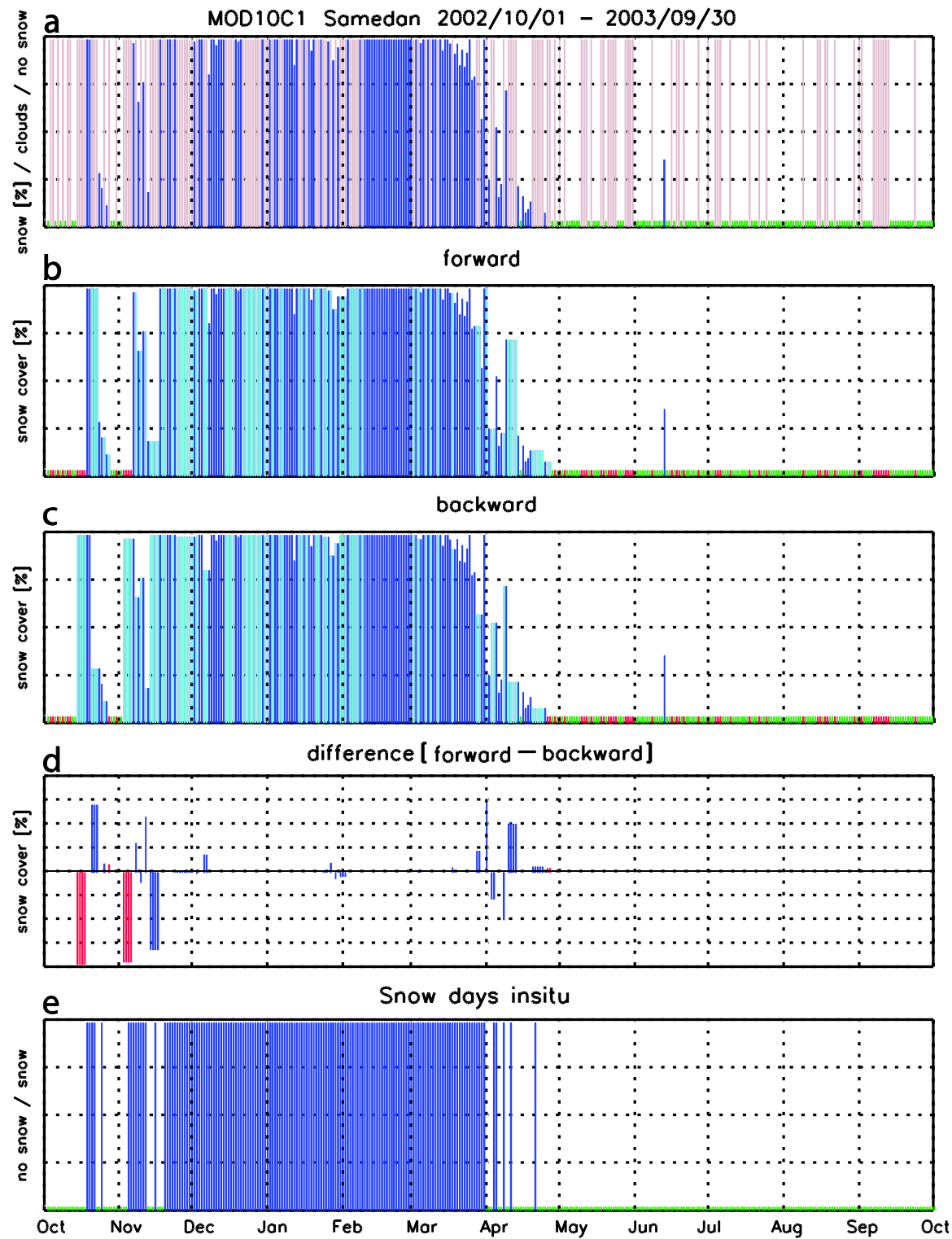

Fig. 4. Processing steps to derive the yearly number of snow days based on the MOD10C1 product (a) by including a forward (b) and backward (c) gap-filling approach. Artificially added snow days (light blue) and days with no snow (light red) are indicated. The differences resulting from the cloud removable technique are visualized (d) with red bars showing a contrary gap-filling and with blue bars showing a consistent gap-filling (i.e. forward $\mathbf{b}$ and backward $\mathbf{c}$ indicate snow). The temporal variability of snow days calculated from in situ observations is demonstrated (e). The period from 1 October 2002 to 30 September 2003 is presented.

\section{Discussion}

The derivation of the yearly number of snow days from the MOD10C1 product is adequate for describing the inter-annual variability of the snow cover over Switzerland. For example, the relatively small number of snow days particularly in the Swiss lowlands is in agreement with monthly temperatures above average for several months between September and June in the years 2001/2002 and 2006/2007 (MeteoSwiss, 2001, 2007). In contrast, completely snow covered Swiss lowlands were observed in the years of 2004/2005 and 2008/2009 due to early snow fall events and winter conditions (MeteoSwiss, 2005, 2009). Although the spatial resolution of the MOD10C1 is moderate $(0.05$ degree) topographic features such as the main alpine valleys are clearly apparent in the product. As such, SCD MODIS provides valuable information to complement the sparsely distributed point observations on the ground.

Analyses at both annual and monthly levels showed that the number of snow days is overestimated by our 
Table 5. Statistical indices for all there sites including daily observations of $\mathrm{SCD}_{\text {MODIS }}$ and $\mathrm{SCD}_{\text {in_situ }}$ from 1 October 2000 to 30 September 2010 based on confusion matrices (hit rate, HIT; false alarm rate, FAR; probability of detection, POD; threat score, TS).

\begin{tabular}{lcccc}
\hline & HIT & FAR & POD & TS \\
\hline Basel & 0.88 & 0.30 & 0.36 & 0.53 \\
Samedan & 0.89 & 0.04 & 0.90 & 0.88 \\
Lugano & 0.94 & 0.16 & 0.54 & 0.49 \\
\hline
\end{tabular}

post-processed MOD10C1 product. For the lowland stations in the northern (Basel) and southern (Lugano) part of Switzerland, the absolute deviations are smaller compared to Samedan on a yearly basis from 2000-2010. However, for the alpine site Samedan, the relative error ( $\mathrm{SCD}_{\mathrm{MODIS}}-\mathrm{SCD}_{\mathrm{in}_{\text {_situ}}}$ ) averaged over the $10 \mathrm{yr}$ is significantly smaller $(8 \%)$ than for Basel $(54 \%)$ or Lugano $(67 \%)$. The overestimation is also shown by a higher commission error rate of $\mathrm{SCD}_{\mathrm{MODIS}}$ (e.g. $3.7 \%$ for Samedan) than the error rate of omission (e.g. $1.5 \%$ for Samedan). This could also be observed for Lugano. Thus, the post-processed MOD10C1 product appears to have a tendency to retrieve too many snow days compared to $\mathrm{SCD}_{\text {in_situ. }}$ A small percentage of about $4 \%$ (for Lugano) to $9 \%$ (for Basel) of all days with contradictory results from the forward and backward gap-filling approach (e.g. $\mathrm{SCD}_{\mathrm{F}_{\text {_snow }}}$ and $\mathrm{SCD}_{\mathrm{B}_{-} \text {snowfree}}$ ) compared to $\mathrm{SCD}_{\text {in_situ }}$ (e.g.

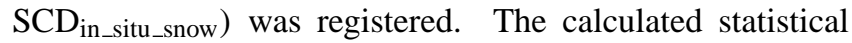
indices (e.g. POD, TS) revealed an overall encouraging performance for the alpine site of Samedan. In contrast, the higher FAR values at Lugano and Basel indicated that in roughly $16 \%-30 \%$ of the satellite derived snow days (SCD MODIS) snow was not observed.

The overall positive bias could not be related directly to the amount of cloudy pixels over the whole period (cloud cover Basel: 50.6\%, Lugano: $38.8 \%$, Samedan: 42.3\%), introducing uncertainty in filling the gaps with either snow or no-snow. The frequency of cloud occurrence and its temporal continuity has probably a higher impact on the accuracy of the number of snow days compared to in situ results. This could be explained by the increase of the uncertainty when the number of consecutive days of cloud obscuration increases. An isolated snow event followed by a period of continuous cloud coverage could lead to a certain overestimation of snow days, which mainly would happen during the transition period in autumn and spring. In contrary, an underestimation might occur when snow falls after a snow free period and cloud coverage remains stable over a region.

The difference between monthly $\mathrm{SCD}_{\text {MODIS }}$ and $\mathrm{SCD}_{\text {in_situ }}$ shows a seasonal variation with the largest differences between October and April. In contrast, differences are smaller during the months with little or no snow (June to September) and the negative $\mathrm{SS}_{\text {clim }}$ values refer to no improvement over the crude estimation of the snow climatology at Samedan.

There are only a few studies (e.g. Wang and Xie, 2009; Gao et al., 2011) focusing especially on snow covered days. Wang and Xie (2009) analysed the performance of MODIS derived mean snow covered days with in situ measured snow covered days for several years at 20 stations in northern China. They observed an overall agreement of $90 \%$ with a relatively higher estimation of snow covered days derived from MODIS. The differences are attributed to the composite algorithm, the point versus pixel observation, the cloud contaminated pixels and various MODIS snow cover classification factors (Wang and Xie, 2009). However, a larger number of studies investigated the accuracy of the diverse MODIS snow cover products over different regions and temporal resolutions.

Several studies described seasonal performance patterns of MODIS products and observed larger MODIS product (e.g. MOD10A2) errors in autumn and smaller errors in spring (Vikhamar and Solberg, 2003; Simic et al., 2004; Parajka and Blöschl, 2006). Concerning the estimation of snow covered days, a similar temporal picture was observed in our results. These mentioned studies linked the larger winter errors to the MODIS snow algorithm and pointed out the need to correct for tree and surface shading effects in winter when solar zenith angles are sub-optimal. Other studies such as Gao et al. (2010) and Klein and Barnett (2003) found the lowest accuracies in the transitional months and refer to more changeable and patchy snow distribution detected by the ground station but not necessarily classified in the corresponding image pixel (i.e. sub-pixel effect). A similar effect might also be apparent for the estimated snow covered days at Samedan in the Central Alps, where a positive bias occurs during the snow accumulation phase (October, November) and during the ablation period (May). In mountainous regions, steep elevation gradients are common and one single MOD10C1 grid cell of 0.05 degree resolution may include both valleys and mountain peaks with e.g. elevation differences up to $1200 \mathrm{~m}$ such as around Samedan. As a consequence, differences are expected when a MOD10C1 grid cell is compared to in situ point observations in complex topography. Additionally, during summer periods the climatological estimates outperform the satellite derived snow days (negative $\mathrm{SS}_{\text {clim }}$ ). The overestimation is also underlined by the percentage of MODIS grid cells defined by the forward and backward gap-filling approach as snow covered (3.7\% of all days) instead of snow free. Furthermore, single snow events, which occur mostly during the transition periods at this altitude, are likely to propagate errors in the final gap-filled product due to the gap-filling technique. 


\section{Conclusions and outlook}

This study presented inter-annual variations of snow cover days (SCD) over Switzerland for the period 2000 to 2010 based on the MOD10C1 snow product ( $\mathrm{SCD}_{\mathrm{MODIS}}$ ). The total annual SCD were retrieved by applying a gap-filling approach to reduce cloud cover obscuration. The gap-filling methodology proposed substitutes cloud covered pixels accounting for around $30 \%$ (Lugano) to $50 \%$ (Samedan) of all pixels over the whole period. Through the presented method, annual snow day maps were derived from 2000 to 2010 over Switzerland. The MOD10C1 product with a moderate grid resolution of 0.05 degree was shown to be adequate to describe the temporal and spatial variation of snow days over Switzerland on a yearly basis.

An accuracy assessment based on three in situ observation sites representing different climatological regimes in Switzerland (Basel, Samedan and Lugano) demonstrated the potential of the SCDMODIS. The correlation between the satellite-derived annual number of snow days and those calculated from in situ observations $\left(\mathrm{SCD}_{\text {in_situ }}\right)$ is high (0.88) with a mean absolute difference of -6.6 days for the three stations combined. To better understand the annual differences in detail, investigations of $\mathrm{SCD}_{\mathrm{MODIS}}$ on the monthly and daily resolution have been conducted. On a monthly basis, the discrepancies between $\mathrm{SCD}_{\text {MODIS }}$ and $\mathrm{SCD}_{\text {in_situ }}$ vary with higher mean absolute differences during the snow accumulation period in autumn and smaller differences after spring. These seasonal findings are in line with other studies mainly focusing on MODIS snow product performances. Statistical indicators summarize the overall accuracy of SCDMODIS for the different climatological regimes, represented by the three stations. The day to day comparison of both forward and backward gap-filling approach against $\mathrm{SCD}_{\text {in_situ }}$ indicates an overall agreement of $94 \%$ and $88 \%$ for the Southern Alps and the Central Alps, respectively. For a large part of the months the $\mathrm{SS}_{\text {clim }}$ is positive, referring to an improvement over the climatological estimations based on in situ only. This tendency is demonstrated for all three sites during most of the months from October to April. The impact of the gap-filling approach was visualized on a daily basis for all three stations over the entire period from 2000 to 2010 . In $1.2 \%$ of all days the MODIS gap-filling approach has erroneously classified snow free days as snow covered for the Swiss Plateau and in $3.7 \%$ of all days for the Central Alps, respectively.

For further discussion of the spatiotemporal variability of snow days on a regional to local scale, other higher spatial resolution products from MODIS or other sensors might be used. The calculation of newly published snow duration parameters such as Snow Cover Index as well as Snow Cover Onset and Melting Dates (Wang and Xie, 2009) are of interest to adapt for Switzerland. The longer record of satellite data such as from NOAA AVHRR might provide more significant long-term information on the change and variability of snow days over Switzerland although other challenges would arise. Additionally, the use of high temporal resolution data such as from geostationary satellites (e.g. Meteosat) could be of interest for the development of a combined gap-filling approach.

Acknowledgements. The authors very much appreciated the careful and detailed review by the two anonymous referees. We wish to thank also Simon C. Scherrer and Fabio Fontana for their valuable input to the manuscript. The MODIS MOD10C1 data (Collection 5) were obtained through the Warehouse Inventory Search Tool (WIST) from the National Snow and Ice Data Center (NSIDC) of the Earth Observing System Data and Information System (EOSDIS).

Edited by: D. Hall

\section{References}

Abegg, B., Agrawala, S., Crick, F., and de Montfalcon, A.: Climate change impacts and adaptation in winter tourism', in: Climate change in the European Alps: Adapting winter tourism and natural hazards management, edited by: Agrawala, S., Paris, OECD Publishing, 2007.

Ackerman, S. A., Strabala, K. I., Menzel, P. W. P., Frey, R. A., Moeller, C. C., and Gumley, L. E.: Discriminating clear sky from clouds with MODIS, J. Geophys. Res., 103, 32141-32157, 1998.

Armstrong, R. L. and Brodzik, M. J.: Recent Northern Hemisphere snow extent: A comparison of data derived from visible and microwave satellite sensors, Geophys. Res. Lett., 28, 3673-3676, 2001.

Bales, R. C., Dressler, K. A., Imam, B., Fassnacht, S. R., and Lampkin, D.: Fractional snow cover in the Colorado and Rio Grande basins, 1995-2002, Water Resour. Res., 44, W01425, doi:10.1029/2006WR005377, 2008.

Beniston, M.: Variations of snow depth and duration in the Swiss Alps over the last 50 years: links to changes in large-scale climatic forcings, Climatic Change, 36, 281-300, 1997.

Bezzola, B. M.: OBS Augenbeobachtungen Lehrbuch zur meteorologischen Augenbeobachtung von MeteoSchweiz, Technical Report MeteoSwiss, 2004 (in German).

Boi, P.: Snow cover retrieval over Italy and alpine regions using MSG data for climatologic purposes, Meteorol. Appl., 17, 313320, 2010.

De Ruyter de Wildt, M., Seiz, G., and Grün, A.: Operational snow mapping using multitemporal Meteosat SEVIRI imagery, Remote Sens. Environ., 109, 29-41, doi:10.1016/j.rse.2006.12.008, 2007.

Eckel, O.: Über die Schneeverhältnisse von Davos [Snow conditions in Davos]. Jahresbericht der Naturforschenden Gesellschaft Graubündens 75(1936-38), 109-156, 1938 (in German).

Elsasser, H. and Messerli, P.: The vulnerability of the snow industry in the Swiss Alps, Mt. Res. Dev., 21, 335-339, 2001.

Foppa, N., Wunderle, S., Hauser, A., Oesch, D., and Kuchen, F.: Operational sub-pixel snow mapping over the Alps with NOAAAVHRR data, Ann. Glaciol., 38, 245-252, 2004.

Foppa, N., Stoffel, A., and Meister, R.: Synergy of in situ and space borne observation for snow depth mapping in the Swiss Alps, Int 
J. Appl. Earth Obs., online first: doi:10.1016/j.jag.2006.10.001, 2006.

Foppa, N., Walterspiel, J., Asch, A., and Seiz, G.: Satellite-based Climate Products for Alpine Studies within the Swiss GCOS Activities, in: Proceedings of the EUMETSAT Meteorological Satellite Conference, Darmstadt, Germany, 8-12 September 2008, ISBN 978-92-9110-082-8, 2008.

Foster, J. L., Hall, D. K., Kelly, R. E. J., and Chiu, L.: Seasonal snow extent and snow mass in South America using SMMR and SSM/I passive microwave data (1979-2006), Remote Sens. Environ., 113, 291-305, 2009.

Gafurov, A. and Bárdossy, A.: Cloud removal methodology from MODIS snow cover product, Hydrol. Earth Syst. Sci., 13, 13611373, doi:10.5194/hess-13-1361-2009, 2009.

Gao, Y., Hongjie, X., Tandong, Y., and Chongsheng, X.: Integrated assessment on multi-temporal and multi-sensor combinations for reducing cloud obscuration of MODIS snow cover products of the Pacific Northwest USA, Remote Sens. Environ., 114, 16621675, 2010.

Gao, Y., Xie, H., and Yao, T.: Developing snow cover parameters maps from MODIS, AMSR-E and blended snow products, Photogramm. Eng. Rem. S., 77, 351-361, 2011.

Klein, A. G. and Barnett, A. C.: Validation of daily MODIS snow cover maps of the Upper Rio Grande River Basin for the 20002001 snow year, Remote Sens. Environ., 86, 162-176, 2003.

Hall, D. K. and Martinec, J.: Remote sensing of ice and snow. London: Chapman and Hall, 1985.

Hall, D. K. and Riggs, G. A.: Accuracy assessment of the MODIS snow-cover products, Hydrol. Process., 21, 1534-1547, 2007.

Hall, D. K., Riggs, G. A., Salomonson, V. V., DiGirolamo, N. E., and Bayr, K. J.: MODIS snow-cover products, Remote Sens. Environ., 83, 181-194, 2002.

Hall, D. K., Riggs, G. A., Foster, J. L., and Kumar, S.: Development and validation of a cloud-gap filled MODIS daily snow-cover product, Remote Sens. Environ., 114, 496-503, doi:10.1016/j.rse.2009.10.007, 2010.

Hantel, M., Ehrendorfer, M., and Haslinger, A.: Climate sensitivity of snow cover duration in Austria, Int. J. Climatol., 20, 615-640, 2000.

IPCC: Climate Change 2007: The Physical Science Basis. Contribution of Working Group I to the Fourth Assessment Report of the Intergovernmental Panel on Climate Change, edited by: Solomon, S., Qin, D., Manning, M., Chen, Z., Marquis, M., Averyt, K. B., Tignor, M., and Miller, H. L., Cambridge University Press, Cambridge, United Kingdom and New York, NY, USA, 996 pp., 2007.

Laternser, M. and Schneebeli, M.: Long-term snow climate trends of the Swiss Alps (1931-99), Int. J. Climatol., 23, 733-750, 2003.

Marty, C.: Regime shift of snow days in Switzerland, Geophys. Res. Lett., 35, L12501, doi:10.1029/2008GL033998, 2008.

MeteoSwiss: Annual Weather Report, 7 pp., available at: www. meteoswiss.ch, 2001 (in German).

MeteoSwiss: Annual Weather Report, 7 pp., available at: www. meteoswiss.ch, 2005 (in German).

MeteoSwiss: Annual Weather Report, 7 pp., available at: www. meteoswiss.ch, 2007 (in German).

MeteoSwiss: Annual Weather Report, 7 pp., available at: www. meteoswiss.ch, 2009 (in German).
Parajka, J. and Blöschl, G.: Validation of MODIS snow cover images over Austria, Hydrol. Earth Syst. Sci., 10, 679-689, doi:10.5194/hess-10-679-2006, 2006.

Parajka, J. and Blöschl, G.: Spatio-temporal combination of MODIS images - Potential for snow cover mapping, Water Resour. Res., 44, W03406. doi:10.1029/2007WR006204, 2008.

Parajka, J. and Blöschl, G.: MODIS-based Snow Cover Products, Validation, and Hydrologic Applications, in: Multiscale Hydrologic Remote Sensing: Perspectives and Applications, edited by: Chang, N.-B. and Hong, Y., Chapter 9, CRC Press, 550 pp., Print ISBN: 978-1-4398-7745-6, eBook ISBN: 978-1-4398-7763-0, 2012.

Platnick, S., King, M. D., Ackerman, S. A., Menzel, W. P., Baum, B. A., Riédi, J. C., and Frey, R. A.: The MODIS Cloud Products: Algorithms and Examples from Terra, IEEE T. Geosci. Remote, 41, 459-473, 2003.

$\mathrm{Pu}, \mathrm{Z} ., \mathrm{Xu}, \mathrm{L}$. , and Salomonson, V. V.: MODIS/Terra observed seasonal variations of snow cover over the Tibetan Plateau, Geophys. Res. Lett., 34, L06706, doi:10.1029/2007GL029262, 2007.

Riggs, G. A., Hall, D. K., and Salomonson, V. V.: MODIS Snow Products User Guide to Collection 5, Digital Media, 80 pp., 2006.

Robinson, D. A. and Frei, A.: Seasonal variability of Northern Hemisphere snow extent using visible satellite data, Prof. Geogr., 52, 307-315, 2000.

Scherrer, S. C. and Appenzeller, C.: Swiss Alpine snow pack variability: major patterns and links to local climate and large-scale flow, Clim. Res., 32, 187-199, 2006.

Scherrer, S. C., Appenzeller, C., and Laternser, M.: Trends in Swiss alpine snow days - the role of local and large scale climate variability, Geophys. Res. Lett., 31, L13215, doi:10.1029/2004GL020255, 2004.

Scherrer, S. C., Wüthrich, C., Croci-Maspoli, M., Weingartner, R., and Appenzeller, C.: Snow variability in the Swiss Alps 18642009, in review, 2011.

Seiz, G. and Foppa, N.: National Climate Observing System (GCOS Switzerland), Publication of MeteoSwiss and ProClim, 92 pp., 2007.

Seiz, G. and Foppa, N.: National Climate Observing System (GCOS Switzerland), Adv. Sci. Res., 6, 95-102, doi:10.5194/asr6-95-2011, 2011.

Seiz, G., Foppa, N., Asch, A., and De Ruyter de Wildt, M.: Snow Cover Climatology from Meteosat-8, in: Proceedings of the Joint EUMETSAT Meteorological Satellite Conference and the 15th Satellite Meteorology \& Oceanography Conference of the American Meteorological Society, Amsterdam, The Netherlands, p. 50, 24-28 September 2007.

Seiz, G., Foppa, N., Meier, M., and Paul, F.: The Role of Satellite Data Within GCOS Switzerland, Remote Sens., 3, 767-780, doi:10.3390/rs3040767, 2011.

Simic, A., Fernandes, R., Brown, R., Romanov, P., and Park, W.: Validation of VEGETATION, MODIS, and GOES + SSM/I snow-cover products over Canada based on surface snow depth observations, Hydrol. Process., 18, 1089-1104, doi:10.1002/hyp.5509, 2004.

Tekeli, A. E., Akyürek, Z., Şorman, A. A., Şensoy, A., and Şorman, A. Ü.: Using MODIS snow cover maps in modeling snowmelt runoff process in the eastern part of Turkey, Remote Sens. 
Environ., 97, 216-230, doi:10.1016/j.rse.2005.03.013, 2005.

Uhlmann, B., Goyette, S., and Beniston, M.: Sensitivity analysis of snow patterns in Swiss ski resorts to shifts in temperature, precipitation and humidity under condition of climate change, Int. J. Climatol., 29, 1048-1055, 2009.

Vikhamar, D. and Solberg, R.: Subpixel mapping of snow cover in forests by optical remote sensing, Remote Sens. Environ., 84, 69-82, 2003.

Wang, X. and Xie, H.: New methods for studying the spatiotemporal variation of snow cover based on combination products of MOIDS Terra and Aqua, J. Hydrol., 371, 192-200, doi:10.1016/j.jhydrol.2009.03.028, 2009.

Wang, X., Xie, H., Liang, T., and Huang, X.: Comparison and validation of MODIS standard and new combination of Terra and Aqua snow cover products in Northern Xinjiang, China, Hydrol. Process., 23, 419-429, 2009.

Wilks, D. S.: Statistical Methods in the Atmospheric Sciences (Second Edition), International Geophysics Series, 91, 630 pp., 2006.

WMO: Systematic Observation Requirements for Satellite-Based Products for Climate, GCOS-107, WMO TD 1338, 2006.

WMO: Handbook on Climate and Climate Temp Reporting, WMO TD 1188, 2009.
WMO: Implementation Plan for the Global Observing System for Climate in Support of the UNFCCC (2010 Update), GCOS-138, WMO TD 1523, 2010.

Wüthrich, C.: Lange Schneemessreihen der Schweiz Aufarbeitung der längsten Schneemessreihen und Trendanalyse ausgewählter Schneeparameter, Master-Thesis, University of Bern, Switzerland, (in German) 2008.

Wüthrich, C., Scherrer, S., Begert, M., Croci-Maspoli, M., Marty, C., Seiz, G., Foppa, N., Konzelmann, T., and Appenzeller, C.: Die langen Schneemessreihen der Schweiz - Eine basisklimatologische Netzanalyse und Bestimmung besonders wertvoller Stationen mit Messbeginn vor 1961, Technical Report by MeteoSwiss, 233, 33 pp., 2010 (in German).

Xie, H., Wang, X., and Liang, T.: Development and assessment of combined Terra and Aqua snow cover products in Colorado Plateau, USA and northern Xinjiang, China, J. Appl. Remote Sens., 3, 033559. doi:10.1117/1.3265996, 2009.

Zappa, M.: Objective quantitative spatial verification of distributed snow cover simulations - an experiment for the whole of Switzerland, Hydrolog. Sci. J., 53, 179-191, 2008. 